\title{
Makna Wadah Tunggal Organisasi Profesi Advokat Ditinjau Dari Undang-Undang Nomor 18 Tahun 2003 Tentang Advokat
}

\author{
Sudarmono $^{1}$ \\ 1 Fakultas Hukum Universitas Airlangga Surabaya \\ E-mail: bobbysudarmono@gmail.com
}

\begin{abstract}
Article 28 paragraph (1) Advocates Act defined; Advocate organization is the only forum of unrestrained and independent advocate profession which established in accordance with the provisions of the Advocate Act and by the intent and purpose to improve the quality of the advocate profession. This means that there is only one single advocate profession after the Advocate Act is enacted by article 32 paragraph (4) within 2 year(s) there should be only one single Advocates Organization. However, at the present time there are 2 Advocates Organization after the Advocates Act had been settled. Therefore, it is necessary to know what factors cause the dualism in Advocate Organization in Indonesia and what is the form of Advocate Profession Organization single forum should be according to the provisions of Advocates Act number 18 / 2003. This study is a normative juridical study, which is a study focuses to attempt the uses of rules or norms in the present positive law. The approaching method being used is the statute approach, this approach is carried out by examining all laws and regulations related to the legal issues being dealt. along with the statute approach, this study uses the conceptual approach, this approach originated from various perspective and doctrines that has bern developed in law. To comply with the grace period regarding the establishment of a single advocate organization, on December 21, 2004 the Indonesian Bar Association was established by 8 (eight) organizations which mentioned in Article 32 Paragraph (3). The establishment of the Indonesian Bar Association is considered not to have fulfilled the requirements as mandated by the Advocate Law by some Advocates who are members of it. Dissatisfaction towards the Indonesian Bar Association was finally realized in the form of the establishment of Indonesian Advocate Congress. Which lead to a new issues of the fragmentation of Indonesian advocate Organization.
\end{abstract}

Keywords: Organization, Advocade, Single Advocade Organization.

\begin{abstract}
Abstrak
Pasal 28 ayat (1) Undang-Undang Advokat menjelaskan Organisasi Advokat merupakan satu-satunya wadah profesi Advokat yang bebas dan mandiri yang dibentuk sesuai dengan ketentuan Undang-Undang Advokat dengan maksud dan tujuan untuk meningkatkan kualitas profesi advokat. Artinya bahwa hanya ada satu organisasi tunggal profesi advokat setelah Undang-Undang Advokat diberlakukan, dengan ketentuan bahwa dalam Pasal 32 ayat (4) paling lama dalam jangka waktu 2 tahun sudah terbentuk satu organisasi tunggal profesi advokat. Dalam kenyataannya sekarang ini terdapat 2 organisai advokat, yang menyatakan sebagai organisasi advokat sesuai dengan Undang-Undang Advokat. Untuk itu perlu diketahui bagaimanakah bentuk dari makna wadah tunggal organisasi profesi advokat yang sesuai dengan Undang-Undang Nomor 18 Tahun 2003 Tentang Advokat. Penelitian ini
\end{abstract}


merupakan penelitian yuridis normatif, yaitu penelitian yang difokuskan untuk menguji penerapan kaidah atau norma-norma dalam hukum positif yang berlaku. Pendekatan yang digunakan yaitu pendekatan undang-undang (statute approach), pendekatan ini dilakukan dengan menelaah semua undang-undang dan regulasi yang bersangkut paut dengan isu hukum yang sedang ditangani dan pendekatan konseptual (conseptual approach), pendekatan ini beranjak dari pandangan-pandangan dan doktrin-doktrin yang berkembang di dalam ilmu hukum. Untuk memenuhi tenggang waktu tentang pembentukan wadah tunggal organisasi advokat, maka pada tanggal 21 Desember 2004 berdirilah Perhimpunan Advokat Indonesia oleh 8 (delapan) organisasi yang disebutkan di dalam Pasal 32 Ayat (3). Berdirinya Perhimpunan Advokat Indonesia dianggap belum memenuhi syarat seperti yang di amanatkan Undang-Undang Advokat oleh sebagian Advokat yang tergabung di dalamnya. Ketidakpuasan terhadap Perhimpunan Advokat Indonesia, akhirnya di tumpahkan dalam bentuk Kongres Advokat Indonesia. Kini organisasi profesi Advokat Indonesia terpecahpecah.

Kata Kunci: Organisasi, Advokat, Wadah Tunggal.

\section{Pendahuluan}

\subsection{Latar Belakang}

Filosofi diundangkannya Undang-Undang Nomor 18 tahun 2003 tentang Advokat selanjutnya disebut Undang-Undang Advokat merupakan suatu perwujudan Indonesia sebagai negara hukum sebagaimana diatur dalam Pasal 1 angka 3 UndangUndang Dasar 1945, dalam rangka untuk tujuan mewujudkan tata kehidupan bangsa yang sejahtera, aman, tenteram, tertib, dan berkeadilan, maka diperlukan suatu kekuasaan kehakiman yang bebas dari segala campur tangan dan pengaruh dari luar, memerlukan profesi yang bebas, mandiri dan bertanggung jawab, untuk terselenggaranya suatu peradilan yang jujur, adil, dan memiliki kepastian hukum bagi semua pencari keadilan dalam menegakkan hukum, kebenaran, keadilan, dan hak asasi manusia. Advokat sebagai profesi yang bebas, mandiri dan bertanggung jawab dalam menegakkan hukum, perlu dijamin dan dilindungi oleh Undang-Undang demi tercapainya upaya penegakan supermasi hukum.

Undang-Undang Advokat mulai di undangkan pada tanggal 5 April 2003 merupakan payung hukum bagi seluruh Advokat Indonesia dalam menjalankan profesinya sebagai penegak hukum. Menurut pandangan Philippe Nonet dan Philippe Selzink, sebagaimana dipaparkan oleh Otje Salman dan F. Susanto. Undang-Undang Advokat merupakan hukum yang responsif, yaitu tatanan hukum yang mampu menjawab kebutuhan dan aspirasi sosial, dalam hal ini aspirasi dari para advokat agar advokat dapat menjalankan profesinya dengan lebih leluasa dan bertanggung jawab. ${ }^{1}$ Hadirnya Undang-Undang Advokat merupakan perwujudan dari cita-cita para advokat yang terus berjuang untuk menempatkan kedudukan advokat agar setara dengan penegak hukum lainnya seperti Jaksa, Hakim, dan Polisi.

\footnotetext{
${ }^{1}$ Otje Salman, F. Santoso., Beberapa Aspek Sosiologi Hukum, Bandung, Alumni, 2004, Hlm. 97.
} 
Sejak diberlakukannya Undang-Undang Advokat eksistensi advokat Indonesia menjadi semakin kuat, karena Undang-Undang Advokat memberikan kewenangan kepada organisasi advokat sepenuhnya untuk melakukan pengangkatan advokat yang syarat dan ketentuannya diatur di dalam Undang-Undang Advokat. Maka guna meningkatkan kualitas organisasi profesi Advokat dan untuk memudahkan pengawasan (controling) terhadap para advokat Indonesia, advokat harus bersatu dalam satu organisasi profesi advokat sebagaimana yang tertuang dalam Pasal 28 ayat (1) Undang-Undang Advokat. Pasal tersebut menyebutkan bahwa:

“Organisasi Advokat merupakan satu-satunya wadah profesi Advokat yang bebas dan mandiri yang dibentuk sesuai dengan ketentuan Undangundang ini dengan maksud dan tujuan untuk meningkatkan kualitas Advokat."

Organisasi tunggal seperti yang dimaksud dalam Pasal 28 ayat (1) UndangUndang Advokat memiliki keunggulan karena ambiguitas dalam penegakan kode etik profesi dapat dihindari. Kriteria etis dan tidak etis hanya menggunakan satu interpretasi menurut garis kebijakan organisasi. Artinya, tidak ada kemungkinan seorang advokat akan pindah dari satu organisasi ke organisasi lain guna menghindari sanksi akibat pelanggaran kode etik profesi. ${ }^{2}$

Undang-Undang Advokat mengamanahkan dibentuknya single bar association atau wadah tunggal bagi organisasi advokat yang merupakan satu-satunya organisasi bagi advokat yang bebas dan mandiri baik dari intervensi pemerintah dan pihak mana pun. Pembentukan organisasi tunggal profesi advokat merupakan proses yang panjang, keseriusan yang ditunjukan oleh Komite Kerja Advokat Indonesia selanjutnya disebut KKAI yang di bentuk pada tanggal 23 Mei 2002 oleh 8 (delapan) organisasi advokat yang ada sebelum UU Advokat antara lain: ${ }^{3}$

1. Ikatan Advokat Indonesia (IKADIN);

2. Asosiasi Advokat Indonesia (AAI);

3. Ikatan Penasihat Hukum Indonesia (IPHI);

4. Himpunan Advokat dan Pengacara Indonesia (HAPI);

5. Serikat Pengacara Indonesia (SPI);

6. Asosiasi Konsultan Hukum Indonesia (AKHI);

7. Himpunan Konsultan Hukum Pasar Modal (HKHPM);

8. Asosiasi Pengacara Syariah Indonesia (APSI);

Delapan organisasi tersebut diamanahkan untuk sementara secara bersamasama menjalankan tugas dan wewenang sebagaimana disebutkan dalam Pasal 32 ayat (3) Undang-Undang Advokat bahwa "Untuk sementara tugas dan wewenang Organisasi Advokat sebagaimana dimaksud dalam Undang-undang ini, dijalankan bersama oleh Ikatan Advokat Indonesia (IKADIN), Asosiasi Advokat Indonesia (AAI), Ikatan Penasehat Hukum Indonesia (IPHI), Himpunan Advokat dan Pengacara

${ }^{2}$ Shidarta, Moralis Profesi Hukum-Suatu Tawaran Kerangka Berfikir, Bandung: Refika Aditama, 2009, Hlm. 107.

3 http://kkaindonesia.blogspot.co.id/2014/07/kkai-sebagai lembaga negara.html\#!/2014 /0 7 /kkai-sebagai-lembaga-negara.html, diakses pada tanggal 29 Mei 2017. 
Indonesia (HAPI), Serikat Pengacara Indonesa (SPI), Asosiasi Konsultan Hukum Indonesia (AKHI), Himpunan Konsultan Hukum Pasar Modal (HKHPM), dan Asosiasi Pengacara Syariah Indonesia (APSI)."

Eksistensi hukum (legal existence) kedelapan organisasi advokat yang diakui sebelum Undang-Undang Advokat tersebut hanya berlaku paling lama 2 (dua) tahun atau sampai organisasi profesi advokat yang diperintahkan Undang-Undang Advokat terbentuuk Pasal 32 ayat (4) menyebutkan: "Dalam waktu paling lambat 2 (dua) tahun setelah berlakunya Undang-undang ini, Organisasi Advokat telah terbentuk." Maksudnya bahwa pembentukan organisasi advokat tidak boleh melebihi jangka waktu yang telah di sebutkan dalam Pasal 32 ayat (4) yaitu tidak boleh lebih dari 2 (dua) tahun dari tanggal sejak Undang-Undang Advokat di berlakukan atau selambatlambatnya pada tanggal 5 April 2005 sudah terbentuk satu organisasi advokat yang dibentuk berdasarkan Undang-Undang Advokat.

Untuk mewujudkan perintah Pasal 28 dan ayat (1) dan Pasal 32 ayat (4) Undang-Undang Advokat, yang menginginkan hanya ada satu wadah tunggal bagi profesi Advokat Indonesia, Akhirnya pada tanggal 21 Desember 2004 ke-8 (delapan) organisasi advokat yang sudah ada sebelum Undang-Undang Advokat secara bersama-sama membentuk organisasi advokat melalui Deklarasi Pendirian Perhimpunan Advokat Indonesia selanjutnya disebut PERADI.

Perjalanan panjang menuju wadah tunggal organisasi profesi advokat ternyata tidak berjalan seperti apa yang dimanahkan Undang-Undang Advokat. Kurang dari 1 (satu) tahun setelah dideklarasikannya PERADI sebagai satu-satunya organisasi advokat yang sesuai dengan Undang-Undang Advokat. Dunia advokat Indonesia harus menerima kenyataan perpecahan, karena pada tanggal 30 Mei 2005 dideklarasikan Kongres Advokat Indonesia selanjutnya disebut KAI melalui suatu kongres. KAI kemudian mengklaim sebagai satu-satunya organisasi advokat, dengan berdirinya KAI setelah lahirnya Undang-Undang Advokat, maka terdapat 2 (dua) organisasi advokat yang menyatakan diri sebagai organisasi advokat yang sesuai dengan Undang-Undang Advokat.

Terhadap perpecahan organisasi advokat Mahkamah Agung mengambil sikap dengan mengeluarkan Surat Keputusan Mahkamah Agung Nomor 052/KMA/V/2009 tertanggal 01 Mei 2009 yang isinya melarang seluruh pengadilan tinggi di Indonesia untuk melakukan penyumpahan sampai dengan PERADI dan KAI bersatu kedalam satu organisasi. Penyumpahan merupakan salah satu syarat pengangkatan Pasal 4 ayat (1) menyebutkan sebelum menjalankan profesinya, advokat wajib bersumpah menurut agamanya atau berjanji dengan sungguh-sungguh di sidang terbuka Pengadilan Tinggi di wilayah domisili hukumnya'. Sedangkan, ayat (3)nya berbunyi 'Salinan berita acara sumpah sebagaimana dimaksud pada ayat (2) oleh Panitera Pengadilan Tinggi yang bersangkutan dikirimkan kepada Mahkamah Agung, Menteri, dan Organisasi Advokat.

Menanggapi Surat Keputusan Mahkamah Agung tersebut kemudian PERADI diwakili oleh Otto Hasibuan dan KAI diwakili oleh Indra Sahnun Lubis membuat piagam perdamaian nota kesepahaman pada tanggal 24 Juni 2010 yang ditandatangani 
oleh Ketua Mahkamah Agung pada saat itu Harifin A Tumpa. Berdasarkan nota kesepahaman tersebut Mahkamah Agung mengeluarkan SKMA nomor 089/KMA/IV/2010 yang pada intinya mencabut kembali SKMA Nomor 052/KMA/V/2009 tertanggal 01 Mei 2009 dan memerintahkan ketua Pengadilan Tinggi di seluruh Indonesia untuk dapat mengambil sumpah para calon advokat yang telah memenuhi syarat, dengan ketentuan bahwa usul penyumpahan tersebut harus diajukan oleh Pengurus PERADI. Dapat dikatakan bahwa SKMA 089/KMA/VI/2010 menghendaki agar organisasi advokat sesuai dengan Undang-Undang Advokat yaitu hanya ada satu organisasi tunggal profesi advokat yang menjadi wadah bagi seluruh advokat Indonesia.

Munculnya SKMA 089/KMA/IV/2011 tidak mengakhiri kisruh yang terjadi pada organisasi advokat karena terhadap penandatanganan nota kesepahaman yang dilakukan oleh PERADI dan dikubu KAI tidak diterima sepenuhnya oleh kubu KAI. Pada saat penandatanganan nota kesepahaman KAI memiliki masalah internal di mana KAI sendiri terpecah menjadi 2 (dua) kubu. KAI kubu Eggi Sudjana tidak mengakui nota kesepahaman yang ditandangani KAI kubu Indra Shanun Lubis, begitu juga kubu Indra Shanun Lubis yang mempermasalahkan penyebutan nama PERADI sebagai satu-satunya organisasi tunggal profesi advokat. ${ }^{4}$

Akibatnya menimbulkan masalah baru apalagi masih banyak calon advokat diluar PERADI yang ditolak untuk di ambil sumpahnya oleh Pengadilan Tinggi. Atas hal tesebut, MK berdasarkan Putusan MK Nomor 101/PUU-VII/2009 dan Putusn MK nomor 112/PUU/XII/2014 memerintahkan bahwa pelaksanaan pasal 4 ayat (1) Undang-Undang Advokat dilaksanakan murni tanpa melihat organisasi manapun di belakang permohonan sumpah tersebut. ${ }^{5}$

Perpecahan internal ternyata tidak hanya terjadi di kubu KAI. PERADI kini juga terpecah menjadi 3 (tiga) kubu dimana masing-masing mengklaim sebagai Ketua Umum PERADI yang sah. Dampaknya Mahkamah agung mengeluarkan SKMA No. 73/KMA/HK.01/IX/2015 yang pada intinya mencabut SKMA-089 tentang penyumpahan advokat.

Sejak dicabutnya SKMA-089 dan dikeluarkannya Putusan MK nomor 112/PUU/XII/2014 maka organisasi advokat semakin terpecah-pecah karena pada saat ini organisasi advokat di luar PERADI dan KAI bisa menyelenggarakan penyumpahan ke Pengadilan Tinggi untuk melantik calon-calon advokat. Putusan Mahkamah Konstitusi menyebutkan bahwa pelaksanaan penyumpahan di pengadilan tinggi sebagai syarat bagi advokat untuk bisa berpraktek baik di dalam maupun di luar pengadilan dilaksanakan murni tanpa melihat organisasi manapun di belakang permohonan sumpah seseorang menjadi advokat. Hal ini membuat pencari keadilan semakin bingung dalam memilih jasa hukum yang berkompeten, banyaknya organisasi advokat akan berdampak kepada sulitnya

${ }^{4}$ http://www.hukumonline.com/berita/baca/lt4c236e3aded5d/perdamaian-semu-peradikai diakses pada tanggal 3 Juni 2017.

${ }^{5}$ https://issuu.com/alsaindonesia/docs/organisasi_advokat_indonesia.docx diakses pada tanggal 3 Juni 2017. 
penegakan kode etik terhadap advokat yang melanggar ketentuan kode etik profesi. Oleh karena itu, penulis merasa perlu untuk melakukan penelitian tentang Organisasi Profesi Advokat ditinjau dari Undang-undang Nomor 18 Tahun 2003 Tentang Advokat.

\section{Metode Penelitian}

Tipe Penelitian ini adalah Yuridis Normatif (legal research) yaitu penelitian yang difokuskan untuk menguji penerapan kaidah atau norma-norma dalam hukum positif yang berlaku. 6 Penelitian hukum memiliki beberapa pendekatan yang digunakan untuk mendapatkan informasi dari berbagai aspek mengenai isu yang sedang dicoba untuk dicari jawabannya. Pendekatan yang akan digunakan penulis yaitu; Pendekatan undang-undang (statute approach), pendekatan ini dilakukan dengan menelaah semua undang-undang dan regulasi yang bersangkut paut dengan isu hukum yang sedang ditangani; dan Pendekatan konseptual (conseptual approach), pendekatan ini beranjak dari pandangan-pandangan dan doktrin-doktrin yang berkembang di dalam ilmu hukum. Dengan mempelajari pendangan-pandangan dan doktrin-doktrin di dalam ilmu hukum, penulis akan menemukan ide-ide yang melahirkan pengertianpengertian hukum, konsep-konsep hukum, dan asas-asas hukum yang relevan dengan isu yang dihadapi. Metode pengumpulan bahan hukum dalam penelitian ini dengan melakukan penelusuran kepustakaan baik berupa bahan hukum primer maupun sekunder. Proses analisis bahan hukum merupakan proses menemukan jawaban dari pokok permasalahan. Proses tersebut dimulai dari pengumpulan bahan-bahan untuk disusun secara sistematis dan dilanjutkan dengan menganalisis bahan penelitian secara cermat. Hasil analisis bahan hukum tersebut kemudian dibahas guna menghasilkan jawaban dan memberikan pemahaman terhadap permasalahan tersebut ditarik suatu kesimpulan yang dilakukan dengan menggunakan metode deduktif. Penggunaan metode ini dengan cara analisis dari kesimpulan umum terlebih dahulu kemudian diuraikan menjadi fakta-fakta yang menjelaskan kesimpulan tersebut.

\section{Hasil dan Pembahasan}

\section{a. Fungsi Dan Peran Advokat Dalam Prores Penegakan Hukum Di Indonesia}

Organisasi advokat secara nasional bermula dari didirikannya Persatuan Advokat Indonesia, pada tanggal 14 Maret 1963. Persatuan Advokat Indonesia kemudian mengadakan Kongres Nasional yang kemudian melahirkan Organisasi advokat yang diberi nama Persatuan Advokat Indonesia yang berdiri pada tanggal 30 Agustus 1964. Pada masanya Persatuan Advokat Indonesia dapat menunjukan diri sebagai suatu organisasi profesi yang terkenal sehingga muncul kesan bahwa Persatuan Advokat Indonesia memonopoli bantuan hukum. Atas prakarsa dari

${ }^{6}$ Marzuki, Peter Mahmud, Penelitian Hukum, Edisi Revisi, Jakarta, Kencana Prenada Media Group, 2013, Hlm. 60 . 
pemerintah untuk mempersatukan seluruh advokat Indonesia di dalam satu wadah tunggal, pada tahun 1985 untuk pertama kali dibuat kongres yang diikuti oleh seluruh advokat dari berbagai organisasi advokat yang ada di Indonesia pada masa itu. Pada kongres itu terbentuk organisasi advokat yang bernama Ikatan Advokat Indonesia tepatnya pada tanggal 10 November 1985.

Terbentuknya Ikatan Advokat Indonesia tidak terlepas dari peran pemerintah untuk menghilangkan eksistensi Persatuan Advokat Indonesia yang dianggap terlalu vokal. Ikatan Advokat Indonesia yang dalam pembentukannya dijadikan sebagai organisasi advokat yang mampu mempersatukan para advokat dalam satu wadah tunggal. Sebagai ketua dan sekertaris pertama adalah Harjono Tjitrosoebono dan Djohan Djauhari. Pada perjalanannya selanjutnya ternyata Ikatan Advokat Indonesia dianggap gagal mempersatukan para advokat dalam satu wadah tunggal. ${ }^{7}$

Pada tanggal 9 Mei 1987 berdiri Ikatan Penasehat Hukum Indonesia di Surabaya yang pendiriannya di latarbelakangi kebijakan pembatasan untuk menjadi anggota Ikatan Advokat Indonesia yaitu harus seorang advokat, sehingga para pengacara praktek yang membutuhkan organisasi memilih untuk membentuk Ikatan Penasehat Hukum Indonesia.

Pada tanggal 5 April 2003 disahkan dan mulai deberlakukan Undang-Undang Nomor 18 tahun 2003 tentang Advokat. Undang-Undang ini mengatur tentang advokat dan organisasi advokat, ketentuan pada pasal 32 ayat (3) dan (4), para pemimpin delapan organisasi pada tanggal 16 Juni 2003 membuat keputusan bersama membentuk Komite Kerja Indonesia. Pada tanggal 21 Desember 2004 para pemimpin delapan organisasi sebelum Undang-Undang advokat di sahkan dan di berlakukan menyatakan membentuk atau mendirikan "Perhimpunan Advokat Indonesia. ${ }^{8}$

Akan tetapi, sekali lagi pembentukan Perhimpunan Advokat Indonesia tersebut menimbulkan polemik di beberapa anggota organisasi advokat, para advokat yang tidak puas dengan kinerja Perhimpunan Advokat Indonesia berkumpul melakukan Kongres pertama di Balai Sudirman Jakarta dan lahir Kongres Advokat Indonesia pada tanggal 30 Mei 2008. ${ }^{9}$

Dalam kedudukannya sebagai sutau profesi yang mulia atau lebih dikenal dengan istilah officium nobile, maka advokat berdasarkan Undang-Undang Nomor 18 Tahun 2003 tentang Advokat, memiliki kewajiban dalam memberikan bantuan hukum secara cuma-cuma (Probono) untuk kaum miskin dan buta huruf. Secara ideal dapat

${ }^{7}$ Irawan Santoso, Pecah Sepanjang Sejarah,

http://irawan santoso.blogspot.com/2008/05/advokat-pecah-sepanjang-sejarah.html, Diakses pada Tanggal 18 Desember 2009.

${ }^{8}$ Agusman Candra Jaya, Advokat, Pengenalan Secara Mendasar Dan Menyeluruh, Bersatulah Advokat Indonesia, Jakarta, Candra Jaya Institute (Pusat Informasi Dan Pelatihan Hukum), 2009, Hlm. 63-65.

9 Frans Hendra Winarta, "Konflik Antar Organisasi Advokat Sekarang dan Solusinya"http://indonesianlawyeronline.com/index.php?option=com_content\&view $=$ article \&id=179:ko nflik-antar-organisasi-advokat-sekarang-dan-solusinya-\&catid=95:opini\&Itemid=296, Diakses tanggal 20 Oktober 2009 
dijelaskan bahwa bantuan hukum merupakan tanggung jawab sosial dari advokat. Oleh sebab itu maka advokat dituntut agar dapat memberikan waktu dan juga sumber daya yang dimilikinya untuk orang miskin yang membutuhkan bantuan hukum secara cuma-cuma. Pemberian bantuan hukum oleh advokat bukan hanya dipandang sebagai suatu kewajiban, namun harus dipandang pula sebagai bagian dari kontribusi dan tanggung jawab dalam kaitannya dengan peran dan fungsi dari profesi advokat. Undang-Undang Nomor 18 Tahun 2003 tentang Advokat telah mengatur mengenai kewajiban advokat untuk memberikan bantuan hukum tanpa tidak membeda-bedakan klien yang ditangani walaupun klien tersebut menerima jasa hukum dari advokat tersebut secara cuma-cuma. Hal ini dipertegas dalam Pasal 22 Undang-Undang Nomor 18 Tahun 2003 tentang Advokat yang menyebutkan bahwa advokat wajib memberikan bantuan hukum secara cuma-cuma kepada pencari keadilan yang tidak mampu. ${ }^{10}$

Bantuan hukum sebagai lazimnya dikonsepsikan sebagai suatu hak yang dapat dituntut oleh setiap umat manusia yang ada di negara kita. Hak yang demikian dipandang sebagai bagian dari pada hak-hak azasi manusia, sehingga dengan demikian program bantuan hukum pada hakekatnya adalah program untuk memperjuangkan penegakan hak-hak azasi manusia. Dengan melalui program bantuan hukum ini di harapkan hak-hak azasi manusia akan diberikan penghargaan yang sepantasnya. ${ }^{11}$

Dalam perkembangannya maka adanya program bantuan hukum juga merupakan bagian yang terpenting dari rekognisi dan perlindungan hak asasi manusia. Pemberian bantuan hukum yang dimaksud disini adalah yang khusus diberikan kepada kaum miskin dan buta huruf. Hak untuk di dampingi advokat (access to legal counsel) merupakan suatu yang imperatif dalam rangka mencapai proses hukum yang adil. Dengan kehadiran advokat dapat dicegah perlakuan tidak adil oleh Polisi, Jaksa, atau Hakim dalam proses interogasi, investigasi, pemeriksaan, penahanan, peradilan, dan hukuman. Sering tersangka atau terdakwa diperlakukan tidak adil dan sampai ada yang disiksa dan direndahkan martabatnya sebagai manusia. ${ }^{12}$ Pada hakekatnya masyarakat dalam konteks negara hukum dan negara demokratis selalu mencari jasa hukum (Legal Service) dan pembelaan (litigation) dari para advokat. Dan advokat dididik dan dilatih untuk melindungi kepentingan masyarakat. ${ }^{13}$

Undang-Undang Dasar 1945 termasuk amandemennya menjelaskan, bahwa permasalahan bantuan hukum tidak dinyatakan secara tegas sebagai beban dan

${ }^{10}$ Setiyono, Kewajiban Pemberan Bantuan Hukum Oleh Advokat Dalam Kedudukannya Sebagai OfficiumNobile, http://www. 2 2sconsulting.com/webs/index.php?option=com content\&view=article \&cat $i d=38 \% 3 A l a w \& i d=27 \% 3 A k e w a j i b a n-p e m b e r i a n-b a n t u a n-h u k u m-o l e h-a d v o k a t-d a l a m-k e d u d u k a n n y a-$ sebagai-officium-nobile-\&Itemid=25.Diakses tanggal 19 Maret 2010

11 Abddurrahman, Beberapa Aspek Tentang Bantuan Hukum di Indonesia, Ditulis Dalam Rangka Proyek Pengembangan Bahan Kuliah Program Penunjang Bantuan Hukum Indonesia Lembaga Kriminologi Universitas Indonesia, Unlam 1980, Hlm. 27.

${ }^{12}$ Frans Hendra Winarta, Bantuan Hukum Suatu Hak Asasi Manusia Bukan Belas Kasihan, Jakarta, PT. Elex Media Komputindo, 2000, Hlm. 104.

${ }^{13}$ Frans Hendra Winarta, Advokat Indonesia Citra Idialisme dan Keprihatinan, Jakarta, Pustaka Sinar Harapan, 1995, Hlm. 37. 
tanggung jawab dari negara. Namun, adanya prinsip-prinsip persamaan di hadapan hukum dan perlakuan yang adil bagi seluruh masyarakat, merupakan petunjuk bahwa Negara wajib memperhatikan masalah bantuan hukum bagi seluruh warga negara khususnya untuk kaum miskin dan buta huruf. Adanya ketidakseriusan dalam penyelenggaraan bantuan hukum oleh negara merupakan pelanggaran terhadap hak asasi manusia yang juga diartikan telah bertentangan dengan hak konstitusional warganegaranya. ${ }^{14}$ Negara bukan merupakan subjek tunggal yang memiliki keterkaitan dengan tanggung jawab pelaksanaan bantuan hukum. Dalam kedudukannya sebagai sutau profesi yang mulia atau lebih dikenal dengan istilah officium nobile maka advokat, berdasarkan Undang-Undang Nomor 18 Tahun 2003 tentang Advokat, juga memiliki kewajiban dalam implementasi bantuan hukum untuk kaum miskin dan buta huruf. Secara ideal dapat dijelaskan bahwa bantuan hukum merupakan tanggung jawab sosial dari advokat. Oleh sebab itu maka advokat dituntut agar dapat mengalokasikan waktu dan juga sumber daya yang dimilikinya untuk orang miskin yang membutuhkan bantuan hukum secara cuma-cuma atau probono. Pada dasarnya, bantuan hukum secara cuma-cuma atau probono yang diberikan oleh advokat memang lebih mengarah kepada fungsi sosial dari profesi advokat. (Setiyono, Loc.cit.) Bantuan hukum telah diatur dalam beberapa pasal dalam Herziene Indische Reglement (HIR). Dalam perkembangannya, maka pengaturan bantuan hukum juga telah diatur dalam berbagai bentuk peraturan mulai dari Undang-Undang sampai dengan Surat Keputusan. Sebagaimana yang dijelaskan dalam Pasal 35, Pasal 36 dan Pasal 37 Undang-Undang Nomor 14 Tahun 1970 tentang Ketentuan-Ketentuan Pokok Kekuasaan Kehakiman berikut dengan perubahannya dalam Undang-Undang Nomor 35 Tahun 1999 menegaskan bahwa setiap orang yang terlibat dalam perkara berhak untuk memperoleh bantuan hukum baik dalam perkara pidana ataupun perdata.

Undang-Undang Nomor 8 Tahun 1981 tentang Hukum Acara Pidana atau yang lebih dikenal dengan sebutan Kitab Undang-Undang Hukum Acara Pidana ternyata mengatur secara tegas soal pemberian bantuan hukum tersebut. Sebagaimana yang dijelaskan dalam ketentuan Pasal 54, Pasal 55 dan Pasal 56 Kitab Undang-Undang Hukum Acara Pidana menerangkan bahwa pemberian bantuan hukum tersebut dimulai dari tingkatan pemeriksaan pendahuluan di tingkat penyidikan sampai dengan pemeriksaan di pengadilan. Namun demikian Kitab Undang-Undang Hukum Acara Pidana juga memiliki keterbatasan dalam pemberian bantuan hukum yang akan dilakukan oleh advokat. Keterbatasan tersebut dalam bentuk tidak diberikannya kesempatan untuk melakukan pembelaan yang bersifat aktif dalam proses pendampingan di tingkat penyidikan. Selain itu, dengan diberlakukannya Kitab Undang-Undang Hukum Acara Pidana maka ketentuan HIR yang mengatur mengenai hukum acara pidana dinyatakan sudah tidak berlaku lagi.

Undang-Undang Nomor 18 Tahun 2003 tentang Advokat juga mengatur secara umum tentang adanya konsep pemberian bantuan hukum. Sebagaimana yang dijelaskan dalam Pasal 22 ayat (1) Undang-Undang Nomor 18 Tahun 2003 dinyatakan bahwa Advokat wajib memberikan bantuan hukum secara cuma-cuma kepada pencari keadilan yang tidak mampu. Untuk kepentingan pembangunan di bidang hukum

${ }^{14}$ Setiyono, Loc.cit. 
khususnya dalam rangka meningkatkan kesadaran hukum mayarakat, menjamin penegakan hukum dan kepastian hukum serta pelayanan hukum maka dilakukan upaya yang dinamakan dengan gerakan bantuan hukum. Dalam kaitannya dengan hal tersebut maka tujuan dari adanya kegiatan bantuan hukum adalah untuk mengadakan perubahan sikap walaupun itu bukan merupakan tujuan yang terakhir yang ingin dicapai oleh adanya bantuan hukum.( Setiyono, Loc.cit.) Hal ini mengingat bahwa dalam suatu negara berkembang masih banyak terdapat individu atau keluarga yang hidup miskin bahkan di bawah garis kemiskinan. Bantuan hukum yang diberikan oleh advokat tersebut tentunya berpedoman pada penghargaan terhadap nilai kemanusiaan termasuk didalamnya penghargaan terhadap Hak Asasi Manusia. Selanjutnya, kewajiban memberikan bantuan hukum tersebut diharapkan mampu memberikan kesadaran dan pengetahuan khususnya mengenai hak-hak dari kaum miskin yang semakin lama dimarjinalkan oleh kebijakan dan proses pembangunan.

\section{b. Makna Wadah Tunggal Organisasi Profesi Advokat Indonesia Yang Sesuai Dengan Undang-Undang Nomor 18 Tahun 2003 Tentang Advokat}

Wadah Tunggal advokat adalah satu-satunya wadah khusus untuk segala profesi yang terkait dengan layanan jasa hukum yang tergabung dalam profesi advokat sebagaimana diatur dalam Undang-Undang Advokat. Undang-Undang Advokat mensyaratkan adanya wadah tunggal advokat guna memudahkan pembinaan, pengawasan, pengenaan sanksi serta peningkatan mutu profesi, dalam kerangka melindungi kepentingan publik. 15

Terdapat banyak organisasi advokat pada satu sisi memiliki kerumitan sendiri, karena akan mempengaruhi pembinaan advokat, yang lebih cenderung ke arah meninggikan value kelompoknya daripada persaingan yang sehat dalam rangka pengabdian kepada hukum itu sendiri. Dalam kaitan ini, keberagaman bisa menjadi ancaman memperlemah posisi advokat secara keseluruhan di mata masyarakat dan negara, khususnya di hadapan para stakeholder yaitu aparat penegak hukum lainnya. ${ }^{16}$

Undang-Undang Nomor 18 Tahun 2003 tentang Advokat mengamantkan bahwa hanya akan ada satu organisasi advokat yang dapat mempersatukan para advokat dalam satu wadah yaitu wadah tunggal, sesuai dengan amanat Pasal 28 ayat (1) Organisasi advokat merupakan satu-satunya wadah profesi advokat yang bebas dan mandiri yang dibentuk sesuai dengan ketentuan Undang-Undang ini dengan maskud dan tujuan untuk meningkatkan kualitas profesi advokat.

15

(Iming M. Tesalonika, Menuju Wadah Tunggal Advokat Yang Ideal, http://webcache.googleusercontent. com/search?q=cache:lV6x3 NSHE8J:www.tesalonika.com/homelfiles/Menuju\%2520Wadah\%2520Tung gal\%2520Advokat\%2520yang\%2520Ideal.doc + manfaat + wadah + tung gal $\& c d=1 \& h l=i d \& c t=c \operatorname{lnk} \& g l=i d$, Diakses pada tanggal 20 Juni 2010.)

${ }^{16}$ Frans Hendra Winarta, 2000, Loc.cit. 
Dengan adanya organisasi tunggal profesi advokat, rekrutmen calon advokat dapat dilaksanakan secara independen, transparan, akuntabel dan profesional dengan menerapkan faktor kognitif dan psikomotorik (kecerdasan intelektual dan penguasaan hukum) dan faktor efektif (integritas dan komitmen yang kuat terhadap penegakan hukum dan keadilan) secara seimbang. Organisasi tunggal profesi advokat juga diharapkan dapat mengadakan suatu pendidikan profesi advokat yang bermutu dan tepat, sehingga menghasilkan advokat-advokat yang handal. ${ }^{17}$

Dengan produk advokat yang handal dan mampu mengikuti perkembangan zaman diharapkan dunia hukum di Indonesia juga akan bertambah maju. Sistem rekrutmen dan pelaksanaan rekrutmen serta ujian dan pelatihan sebaiknya diserahkan kepada lembaga independen yang ditunjuk organisasi profesi advokat (bar association) untuk mencegah komersialisasi sertifikasi dan mencegah konflik kepentingan (conflict of interest) dan subyektifitas.

Advokat sebagai bagian dari sistem penegakan hukum juga harus menampilkan eksistensinya yang terbaik artinya advokat harus membuktikan kemampuan dan komitmennya terhadap penegakan hukum. Bila kinerja advokat semakin profesional, stigmatisasi yang buruk terhadap advokat sedikit demi sedikit akan hilang. Tidak bisa diingkari masih ada oknum-oknum advokat yang menjalankan profesinya secara tidak profesional, seperti menyuap hakim, jaksa dan polisi kemudian juga menjadi calo perkara.

Demi kepentingan nasional, bersatulah advokat Indonesia, dualisme organisasi advokat harus cepat disatukan. Jika semuanya teratasi dan berjalan lancar maka advokat dapat berperan maksimal dalam reformasi hukum di Indonesia, kalau tidak, organisasi advokat ini akan menjadi sebuah antithesis. Untuk itu, para pemimpin organisasi advokat harus berjiwa besar dan rela berkorban untuk kepentingan bangsa dan negara untuk melepaskan ego masing-masing dan bersatu dalam organisasi profesi advokat tunggal, kuat dan berintegritas. Jadikanlah profesi advokat ini sebagai the guardian of the constitution demi pencapaian negara hukum (rechtstaat) yang kuat. ${ }^{18}$

\section{Kesimpulan}

Fungsi dan peran Advokat dalam proses penegakan hukum di Indonesia salah satunya adalah memberikan bantuan hukum kepada pencari keadilan yang tidak mampu. Undang-Undang Nomor 18 Tahun 2003 tentang Advokat mengatur secara umum tentang adanya konsep pemberian bantuan hukum. Sebagaimana yang dijelaskan dalam Pasal 22 ayat (1) Undang-Undang Nomor 18 Tahun 2003 menyatakan bahwa Advokat wajib memberikan bantuan hukum secara cuma-cuma (Probono) kepada pencari keadilan yang tidak mampu. Pemberian bantuan hukum oleh advokat tidak hanya dipandang sebagai suatu kewajiban, namun harus dipandang pula

17 Abi Jumroh Harahap Dan Jujur Halasan Bakara, Bersatulah Advokat Indonesia, http:// libray+USU,Abi+Jumroh+Harahap+Dan+Jujur+Halasan+Bakara\%2C+Bersatulah+Advokat+Indones ia._Diakses pada tanggal 10 Februari 2010.

${ }^{18}$ Abi Jumroh Harahap Dan Jujur Halasan Bakara, Loc.Cit. 
sebagai bagian dari kontribusi dan tanggung jawab dalam kaitannya dengan fungsi dan peran dari profesi advokat dalam penegakan hukum di Indonesia.

Bentuk dari makna wadah tunggal di jelaskan di dalam Pasal 28 ayat (1) yang berbunyi : Organisai advokat merupakan satu-satunya wadah profesi advokat yang bebas dan mandiri yang dibentuk sesuai dengan ketentuan Undang-Undang ini dengan maksud dan tujuan untuk meningkatkan kualitas profesi advokat. Pasal 28 ayat (1) mengandung arti bahwa hanya ada satu organisasi tunggal profesi advokat setelah Undang-Undang Advokat diberlakukan dengan ketentuan paling lama dalam jangka waktu 2 tahun sudah terbentuk satu organisasi tunggal profesi advokat. Dalam perkembangannya sekarang ini terdapat lebih dari organisasi profesi advokat di Indonesia. Banyaknya organisasi advokat di Indonesia akan berdampak kepada sulitnya penegakan kode etik kepada advokat yang melanggar ketentuan kode etik profesi advoakat dan tentunya hal ini sangat membingungkan, para pencari keadilan.

\section{Daftar Pustaka}

\section{Buku}

Otje Salman, F. Susanto, Beberapa Aspek Sosiologi Hukum, Alumni, Bandung, 2004.

Shidarta, Moralitas Profesi Hukum-Suatu Tawaran Kerangka Berpikir, Refika Aditama, Bandung, 2009.

Abddurrahman, Beberapa Aspek Tentang Bantuan Hukum di Indonesia, Ditulis Dalam Rangka Proyek Pengembangan Bahan Kuliah Program Penunjang Bantuan Hukum Indonesia Lembaga Kriminologi Universitas Indonesia, Unlam, 1980.

Frans Hendra Winarta, Bantuan Hukum Suatu Hak Asasi Manusia Bukan Belas Kasihan, PT. Elex Media Komputindo, Jakarta, 2000.

Frans Hendra Winarta, Advokat Indonesia Citra Idialisme dan Keprihatinan, Pustaka Sinar Harapan, Jakarta, 1995.

Agusman Candra Jaya, Advokat, Pengenalan Secara Mendasar Dan Menyeluruh, Bersatulah Advokat Indonesia, Candra Jaya Institute (Pusat Informasi Dan Pelatihan Hukum), Jakarta, 2009.

Marzuki, Peter Mahmud, Penelitian Hukum, Edisi Revisi, Kencana Prenada Media Group, Jakarta, 2013.

\section{Internet :}

http://kkaindonesia.blogspot.co.id/2014/07/kkai-sebagai lembaga negara.html\#!/2014 /0 7 /kkai-sebagai-lembaga-negara.html, diakses pada tanggal 29 Mei 2017. 
http://www.hukumonline.com/berita/baca/lt4c236e3aded5d/perdamaian-semuperadikai diakses pada tanggal 3 Juni 2017.

https://issuu.com/alsaindonesia/docs/organisasi_advokat_indonesia.docx diakses pada tanggal 3 Juni 2017.

Irawan Santoso, Pecah Sepanjang Sejarah, $\underline{\text { http://irawan santoso.blogspot.com/2008/05/ }}$ advokat-pecah-sepanjang-sejarah.html, Diakses pada Tanggal 18 Desember 2009.

Frans Hendra Winarta, "Konflik Antar Organisasi Advokat Sekarang dan Solusinya"http://indonesianlawyeronline.com/index.php?option=com_contentEview= articleEid=179:konflik-antar-organisasi-advokat-sekarang-dan-solusinyaEcatid=95:opiniEItemid=296, Diakses tanggal 20 Oktober 2009.

Setiyono, Kewajiban Pemberan Bantuan Hukum Oleh Advokat Dalam Kedudukannya SebagaiOfficiumNobile, $h \mathrm{ttp}: / / w w w . m 2$ sconsulting.com/webs/index.php?option $=c \mathrm{co}$ m_contentEview=articleEcatid $=38 \% 3$ Alaw $\mathcal{E} i d=27 \% 3$ Akewajiban-pemberianbantuan-hukum-oleh-advokat-dalam-kedudukannya-sebagai-officium-nobileEItemid=25.Diakses tanggal 19 Maret 2010.

Iming M. Tesalonika, Menuju Wadah Tunggal Advokat Yang Ideal, $\underline{\text { tttp://webcache.goog }}$ leusercontent.com/search?q=cache:IV6x3_NSHE8J:www.tesalonika.com/home/files/Me nuju\%2520Wadah\%2520Tunggal \% 2520Advokat\% 2520yang\%2520Ideal.doc+manfaa $t+$ wadah + tunggalEcd $=1 \mathcal{E} h l=i d \mathcal{E} c t=c \ln k \mathcal{E} g l=i d$, Diakses pada tanggal 20 Juni 2010.

Abi Jumroh Harahap Dan Jujur Halasan Bakara, Bersatulah Advokat Indonesia, http:// libray+USU,Abi+Jumroh+Harahap+Dan+Jujur+Halasan+Bakara\%2C+Bersatulah $+A$ dvokat+Indonesia._Diakses pada tanggal 10 Februari 2010. 